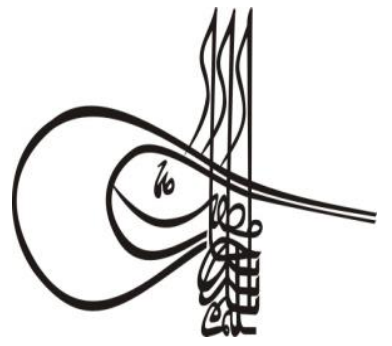

Received/Geliş: 09.09.2019

\section{Turkiglo Studieg Educational Sciences}

Volume 14 Issue 5, 2019, p. 2345-2364 DOI: 10.29228/TurkishStudies.36955

ISSN: 2667-5609

Skopje/MACEDONIA-Ankara/TURKEY

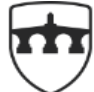

INTERNATIONAL BALKAN UNIVERSITY

EXCELLENCE FOR THE FUTUR IBU.EDU.MK

Research Article / Araştırma Makalesi

Article Info/Makale Bilgisi

$\checkmark$ Accepted/Kabul: 15.10 .2019

Gor Report Dates/Rapor Tarihleri: Referee 1 (07.10.2019)-Referee 2 (10.10.2019)

This article was checked by intihal.net.

\title{
İLKÖĞRETİM MATEMATİK ÖĞRETMENİ ADAYLARININ YAPILANDIRMACI BİR ORTAM DENEYİMİ: KESİRLERİ BİRİM KESİRLERİN TOPLAMI OLARAK YAZMA
}

\author{
Mustafa GÖK* - Melisa ARIK**
}

\begin{abstract}
öz
Günümüz matematik eğitiminde öğrenci merkezli öğretim durumlarının bilinmesi gerekmektedir. Bu doğrultuda bir problemin çözümüne yönelik ortamın oluşturulması, öğrenenlere ortamdan geri dönüt sağlanması ve öğrenci merkezli ortamın gerektirdiği şartlarının korunması matematiksel bilginin yapılandırılmasında büyük bir öneme sahiptir. Öğrenci merkezli ortamlarda matematiksel bilginin yapılandırılmasında matematik eğitim teorilerinden yararlanılabilir. $\mathrm{Bu}$ çalışmanın çıkış noktası öğrenci merkezli bir ortamı deneyimleme yoluyla öğretmen adaylarını öğrenci merkezli ortamların bileşenleri ile karşı karşıya getirmektir. Öğrenci merkezli etkinlikleri deneyimleme bu tür ortamların tasarımının öğretiminde bir yol olarak kullanılabileceği düşünülmektedir. Matematik tarihi bu tür bir deneyimin tasarlanmasına yönelik zengin bir kaynaktır. Bu çalışmanın amacı, ilköğretim matematik ögretmen adaylarına bir problemin -matematik tarihinden alınanöğrenci merkezli bir öğretim ortamında uygulanma sürecini betimlemektir. Araştırmada durum çalışması yöntemi kullanılmıştır. Etkinlik tasarımında ve uygulanmasında Didaktik Durumlar Teorisi'nden (DDT) yararlanılmıştır. DDT öğrenci merkezli ortamların tasarımı ve uygulanması sürecinde etkili yollar sunmaktadır. Çalışmanın katılımcıları amaçlı örnekleme yöntemiyle seçilen ilköğretim matematik öğretmeni aday1 21 (10 kız ve 11 erkek) kissidir. Veriler kamera, ses kayıt cihazı ve öğretmen adaylarına dağıtılan A4 kağıtları aracılığıyla toplanmıştır. Uygulamanın analizi DDT'nin aşamaları doğrultusunda betimlenmiştir. Çalışmanın bulgularından DDT'nin öğrenci merkezli tasarımların öğretiminde etkili olarak kullanılabileceğini göstermiştir. Bu
\end{abstract}

Dr. Öğr. Üyesi, Van Yüzüncü Y11 Üniversitesi, Matematik Eğitimi, E-posta: mustafagok@yyu.edu.tr

Öğretmen, Milli Eğitim Bakanlığı, E-posta: melisa.arik@gmail.com 
tür farklı deneyimlerin lisans öğrenim sürecinde sayısının arttırılmasının öğretmen adaylarının bilmesi gereken öğrenci merkezli ortam tasarımlarına ilişkin birçok farkındalık sağlayacağı düşünülmektedir.

Anahtar Kelimeler: Didaktik Durumlar Teorisi, Adidaktik durumlar, Yapılandırmacı yaklaşım, Öğretmen adayları, Kesirler

\title{
A CONSTRUCTIVIST MILIEU EXPERIENCE OF PRESERVICE ELEMENTARY MATHEMATICS TEACHERS: WRITING FRACTIONS AS SUM OF UNIT FRACTIONS
}

\begin{abstract}
Today, it is necessary to know student-centered teaching situations in mathematics education. In this respect, establishing a milieu for solving a problem, providing feedbacks to learners and maintaining the conditions required by the student-centered environment are of great importance in structuring mathematical knowledge. In a studentcentered environment, mathematics education theories can be utilized in structuring mathematical knowledge. The aim of the study is to bring preservice elementary mathematics teachers together with the components of student-centered environment by experiencing a studentcentered environment. It is believed that experiencing student-centered activities can be used as a way of teaching the design of such environments. The history of mathematics is a rich resource for designing such an experience. The aim of this study is to describe the process of applying a problem taken from the history of mathematics in a studentcentered teaching environment to PEMTs. Case study method was used in the research. Theory of Didactical Situation (TDS) was used in the design and implementation of the activity. TDS provides effective ways of designing and implementing student-centered environment. The participants of the study were 21 (10 females, 11 males) PEMs selected by purposive sampling method. Data were collected via camera, tape recorder and A4 papers distributed to PEMs. The analysis of the implementation was identified within the scope of TDS stages. The results of the study have revealed that TDS can be used effectively in teaching student-centered designs. It is thought that increasing the number of such different experiences during the undergraduate process will provide awareness about student-centered environment designs to be known by PEMTs.
\end{abstract}

\section{STRUCTURED ABSTRACT}

\section{Introduction}

In today's mathematics education, one of the important issues related to teacher education is the gap between theory and practice. This situation is observed more visible in the branches where specific field training is given. For example, it is stated that Preservice Elementary Mathematics Teachers do not experience the theoretical approaches they have learned during their undergraduate studies in practical courses 
(school experience, teaching practice, etc.) sufficiently (Özgür, BukovaGuzel, Kula and Uğurel, 2009; İnan and Özgen, 2008).

Although PEMTs are given theoretical information about studentcentered approaches, it is rarely shown how they can be used in teaching a mathematical concept or object in mathematics education. This study has been carried out with the idea of giving an experience to PEMTs about how to transfer the knowledge they have in theory to practice.

Mathematics education theories can be used to fill the gap between theory and practice in mathematics teaching. One of these approaches is Theory of Didactical Situation (TDS). Therefore, the arguments of TDS are used as the theoretical framework in the study.

TDS can be used effectively in designing student-centered learning environment (Artigue, 1994; Laborde, 2007). The concept of situation has a central function in theory. Situation is defined as the conditions necessary for a student to learn and use mathematical knowledge (Warfield, 2014). The cases designed within the framework of the theory are called adidactical situations (Brousseau, 1997).

Brousseau (1997) stated that there are five stages of adidactical situations. First, in devolution stage, the game should be introduced, and the learners should take responsibility for learning. In the action stage, learners play the game individually or in groups. In this process, they may discover some implicit strategies leading to winning. These strategies are clearly set out in a way that learners understand in the next stage of formulation. These can be expressed as hypotheses. In the validation stage, these hypotheses are proved and corroborated or confuted. At the end of this stage, it is thought that the class can reach the target information in the context of the game. In the institutionalization stage, the target information reached is explained in different ways with examples.

In this study, a cross section from the history of mathematics was used to create the milieu designed within the framework of TDS. There are many studies in the literature regarding the reflections of the use of the history of mathematics in teaching environments (Fried, 2001; Tzanakis, \& Arcavi, 2000).

It has been found that there are very few studies in the literature regarding the design or teaching of a cross-section from the history of mathematics to PEMTs in a student-centered environment. In this context, it is possible to describe the mathematical ideas in the process of solving the Josephus problem (Çelik et. al, 2015), and to introduce the Babylonian method in the square root calculation (Karakuş, 2009) to PEMTs. It could be noted that the history of mathematics provides a rich resource in the teaching of mathematical knowledge and includes alternative ways of finding solutions to the problems related to the teaching of mathematical knowledge. Therefore, a general approach on how to write fractions as the sum of unit fractions to a problem situation in the history of mathematics is sought, PEMTs' ways of finding the solution is examined. Accordingly, answers for the following questions are sought:

- $\quad$ How did PEMTs develop a solution to the problem situation presented in a student-centered environment? 
- Which models have emerged in the solution approaches of PEMTs to the problem situation?

- In what ways could TDS provide awareness to PEMTs in problem-solving process in student-centered environment designs?

\section{Method}

Case study among qualitative research methods was used in the research. In this context, a student-centered activity designed within the framework of TDS was applied to PEMTs familiar with the studentcentered learning environment in their undergraduate studies theoretically. On the other hand, these teachers have not been given the opportunity to apply them before. The activity is designed to teach PEMTs a method of unit fractionation of fractions from the history of mathematics via a game designed according to TDS.

The participants of the study consisted of 21 (10 females and 11 males) PEMTs studying at a public university in the Eastern Anatolia Region. Participants were determined by purposive sampling method. The aim of purposive sampling was to obtain rich data related to the research subject (Yıldırım and Şimşek, 2016).

In this study, a general method is searched for how any simple fraction can be expressed as the sum of unit fractions. In the history of mathematics, it is possible to solve this problem with two general approaches: splitting method and Fibonacci method (Burton, 2011). In this study, PEMTs access to these methods or more local methods and description of the environment in this process were examined.

The data of the study were collected through video camera, tape recorders and field notes (A4 papers, distributed before the activity, photographs, etc.). The data was transferred to the computer by relistening. Then, the data were analyzed.

The data were obtained by describing the approaches of PEMTs at different stages of TDS. Accordingly, the data were analyzed in accordance with the stages shown in Table 1.

\section{Results}

In this section, PEMTs sought solutions to the problem situation adapted from the history of mathematics in the activity designed within the framework of TDS by considering the different stages of TDS. In this context, the results were presented in three sub-headings.

During the stage of devolution, the teacher successfully explained the problem to PEMTs in the context of the game, and it was seen that the PEMTs understood the rules of the game.

The stages of action, formulation and validation were intertwined. At these stages, PEMTs found minimum one solution for each task. In addition, they were able to develop more than one solution in about twothirds of the tasks (see Table 2). Intensive interaction between the groups was observed during the validation of the solution stage. In this process, one of the groups took the position of producing hypothesis and the other took the position to validate (approval or rejection) the given hypothesis. In this way, the dynamic structure of the student-centered environment has been maintained and continuous progress has been made in terms 
of information. Therefore, models have emerged to solve the problem situation. These solutions can be explained in four different models. Three of them are local and one is general (see Table 3).

During the institutionalization stage, these models were explained, and the activity was completed. It can be stated that TDS provides awareness to the PEMTs about how to give the game context to the problem, how to organize the milieu and what teacher-student roles are in the process of problem-solving in a student-centered environment.

\section{Discussion and Conclusion}

It is seen that PEMTs have created at least one solution for each task presented in the study where a solution is sought in a studentcentered environment in relation to a problem situation selected from the history of mathematics. It can be noted that focusing on problem design elements within the framework of TDS is effective in the emergence of these solutions. In student-centered activity design, it could be highlighted that the awareness of future teachers and structuring them will reduce the difference between theory and practice in education. Penuel, Roschelle and Shechtman (2007) stated that teachers' participation in the design process related to their learning situations played a key role in the use of innovative approaches at schools. In today's mathematics curriculum, where student-centered environment is required to be used in teaching situations (MoNE, 2018a), there is no doubt that eliminating the gap between theory and practice regarding the use of student-centered environment is also vital for the professional development of PEMTs.

In this study, it was found that PEMTs developed more than one solution in most of the assigned tasks. It is stated in the literature that students are not willing to find more than one solution to the problem situation designed within the framework of TDS (Erümit, Arslan and Erümit, 2012; Dikkartin Övez, \& Akar, 2018). This study is different from other studies in terms of developing more than one solution by PEMTs regarding a problem situation. Similar to the results of this study, in a study where teachers' actions were examined, it was noted that students could develop different solution approaches regarding the problem situation presented within the framework of TDS and that the roles of teachers in the teaching process affected the emergence of some solution techniques (Sensevy, et al., 2005).

In the implementation process of this activity, the adidactical stages (action, formulation and validation) were intertwined. Arslan, Taşkın and Kirman-Bilgin (2015) noted that when individual and group works were compared, adidactical situations highly supported individual activities. Similarly, it was found that individual arguments for sharing, disseminating and structuring information in the process of interaction within the group were effective in terms of finding the general method.

In this study, it has not been stated that PEMTs internalized the elements of student-centered environment design in the process of solving a problem situation. Instead, it has been noted that there is an awareness among the PEMTs about the components of the studentcentered environment. On the other hand, increasing such experiences during university years has the potential to eliminate the gap between 
the PEMTs' theoretical knowledge of student-centered environment and their use in practice.

Keywords: Theory of Didactical Situation, Adidactical situations, Constructivist approach, Pre-service teacher, Fractions

\section{Giriş}

Günümüz matematik eğitiminde öğretmen eğitimi ile ilgili önemli konularından biri teori ve pratik arasındaki uçurumdur. Bu durum alan eğitimi verilen branşlarda daha da net gözlenmektedir. Örneğin matematik öğretmen adaylarının lisans eğitimleri süresince teorik olarak öğrendikleri yaklaşımları uygulamalı derslerde (okul deneyimi, öğretmenlik uygulaması gibi) yeterince deneyimleyemedikleri belirtilmektedir (Özgür, Bukova-Guzel, Kula ve Uğurel, 2009; İnan ve Özgen, 2008).

Öğretmen adayları mesleki gelişimleri doğrultusunda lisans eğitimlerinde eğitim bilimleri disiplini ile ilgili birçok ders görmektedir. Bu dersler öğretim durumlarına ilişkin genellikle teorik bilgiler içermektedir. Ancak 2018 öncesine kadar öğretmenlik programlarında öğrenci merkezli durumlara ilişkin teorik bilgilerin pratikte nasıl uygulanacağı ile ilgili yeterli sayıda derse yer verilmediği görülmektedir (Yükseköğretim Kurulu [YÖK], 2007). Örneğin ilköğretim matematik öğretmenliği programında teorik anlamda birçok eğitim dersi bulunmasına rağmen bu derslerin alan eğitiminde pratikte nasıl kullanılabileceğine ilişkin programda sınırlı sayıda derse (okul deneyimi ve ögretmenlik uygulaması dersleri gibi) yer verildiği görülmektedir. Bu durum teoride genişçe açıklanan ve önemli olduğu vurgulanan öğrenci merkezli yaklaşımların ilgili alanın öğretiminde (örneğin matematik öğretiminde) uygulamada hayata geçirememesi ile sonuçlanabilmektedir. Bu durumun engellenmesi adına öğretmenlik programlarında değişikliğe gidilmiştir. Teorik bilginin pratikte daha etkili kullanılabilmesine yönelik, öğretmen yetiştiren programlarda 2018 güncellenmesiyle birlikte teori ve pratiğin iç içe olduğu alan eğitimi derslerinin sayısının arttığı görülmektedir (YÖK, 2018). Bu tür güncellemeler yükseköğretimden ilköğretime ya da ortaöğretime doğru olabileceği gibi tersi durumlar da söz konusu olabilmektedir (YÖK, 2007; Malik, 1980).

Matematik öğretiminde öğretmen adaylarına öğrenci merkezli yaklaşımlar ile ilgili teorik bilgiler verilmesine rağmen bunların matematiksel bir kavramın ya da nesnenin öğretiminde nasıl kullanılabileceği nadiren gösterilmektedir. Hargreaves (1996), lisans yıllarında öğrenilen deneyimlerin öğretmenler için yararlı olduğunu ve bunların uygulamadaki süreçleri etkilediğini belirtmiştir. $\mathrm{Bu}$ çalışma öğretmen adaylarına teoride sahip oldukları bilgileri uygulamaya nasıl aktarabileceklerine ilişkin bir deneyimi yaşatma düşüncesiyle ortaya çıkmıştır. Nitekim günümüzde matematik öğretim durumlarında öğrenci merkezli ortamların kullanılması istenmektedir (Milli Eğitim Bakanlığı [MEB], 2018a, 2018b). Bunun en önemli sebebi günümüzde toplumun ihtiyaç duyduğu birey profilinde değişiklik olması ile açıklanabilir. Bu bağlamda gerçek yaşamda karşılaşılan problem durumlarına işbirliği içerisinde ve birlikte çözüm bulma ön plana çıkmaktadır. OECD (2017), ülkemizdeki öğrencilerin işbirlikçi problem çözme becerilerinin çok düşük olduğunu vurgulamaktadır. Bu durumun bir nedeni grup çalışmasını teşvik eden öğrenci merkezli yaklaşımların öğretim sürecinde az ya da hiç kullanılmamasıyla açıklanabilir. Öğretici pozisyonundakilerin bu tür yaklaşımları sadece teoride bilmeleri ve pratikte bunları hayata geçirmede çeşitli zorluklar yaşamaları da öğrenci merkezli ortam tasarımlarının önündeki diğer bir engel olarak gösterilebilir. Bu tür durumların nasıl kullanılması gerektiği içerisinde birçok farklı değişken ve süreç barındırmaktadır. Genel olarak öğrenci merkezli ortamların tasarımı: 1. İlgili matematik eğitim teorilerini bilme, 2. Ortam tasarımını bilme (örneğin problemin nasıl olması gerektiği gibi), 3. Uygulama sürecini bilme (öğrenci-öğrenci ve öğretmenöğrenci etkileşiminin nasıl olması gerektiği gibi) bileşenlerini barındırmaktadır. Bu ortamların nasıl 
tasarlanması gerektiği noktasında ise özellikle alan eğitimi veren programlarda etkili çözümler gözlenmemekte ve öğreten konumundaki kişiler bu konuda yalnız bırakılmaktadır.

Matematik öğretiminde teori ve pratik arasında gözlemlenen boşluk matematik eğitim teorilerinden yararlanılarak çözülebilir. Bu yaklaşımlarda biri Didaktik Durumlar Teorisi (DDT) olarak belirtilebilir. DDT matematiğin öğrenci merkezli ortamlar tasarlanarak öğretilmesi noktasında ve tasarlanan etkinlik uygulanması sürecinde öğretmen ile öğrenci arasındaki etkileşimin sağlanması açısından uygun bir öğretim atmosferi sunmaktadır. Bu yüzden bu çalışmada DDT'nin argümanları kuramsal çerçeve olarak kullanılmıştır.

DDT öğrenci merkezli öğrenme ortamlarının tasarlanmasında etkili olarak kullanılabilmektedir (Artigue, 1994; Laborde, 2007). Teoride durum kavramı merkezi bir işleve sahiptir. Durum matematiksel bir bilgiyi bir öğrencinin kullanmasında ve öğrenmesinde ilgili şartlar olarak tanımlanmıştır (Warfield, 2014). Teori çerçevesinde tasarlanan durumlar adidaktik durumlar olarak belirtilmiştir (Brousseau, 1997).

Adidaktik durumlar, öğretmenin etkilerinin sınırlandırıldığı bir ortamda, öğretilmek istenen matematiksel bilginin öğrencilerden bir süreliğine bir oyun içerisine gömülerek saklandığı ve ortam (milieu) ile öğrencilerin etkileşim içerisinde hedef bilgiyi (kendi bilgilerini) yapılandırdığı durumlardır (Warfield, 2014). Dolayısıyla teoride önemli diğer bir kavram ortamdır. Oyunun oynanması sürecinde kazanma-kaybetme durumları, karşı rakibin stratejileri, tasarlanan bir materyal gibi öğrenci üzerine etki eden her şey ortamı oluşturabilmektedir (Brousseau, 1997). Bu bağlamda öğretmen adaylarına sunulan oyundaki sınırlılıkların ve koşulların üstesinden gelinmesi gerekmektedir. Bu ise ortam ile etkileşime girilerek sağlanmaktadır. Bu yüzden ortamın öğrenenlere pozitif ya da negatif dönüt verecek şekilde özenle tasarlanması gerekmektedir (Erdoğan ve Özdemir Erdoğan, 2013). Bu tür bir ortam tasarlandığında öğretmen adaylarının oyun bağlamında ürettikleri stratejiler ortamdan alınan dönütler ile doğrulanabilir, ortamdaki bilgi sürekli revize edilebilir ve hedef bilgiye doğru bir akış sağlanabilir.

Brousseau (1997), adidaktik durumların beş aşaması olduğunu belirtmiştir. İlk olarak sorumluluk aktarma aşamasında, oyunun tanıtılması ve öğrenmenin sorumluluğunu öğrenenlerin alması gerekmektedir. Eylem aşamasında, öğrenenler oyunu bireysel olarak ya da grup halinde oynamaktadır. $\mathrm{Bu}$ süreçte oyunda kazandıran çoğu örtük bazı stratejiler keşfedebilirler. Bu stratejiler sonraki aşama olan ifade etme aşamasında öğrenenlerin anlayacağı şekilde açıkça ortaya konmaktadır. Bunlar hipotez olarak ifade edilebilir. Doğrulama aşamasında, bu hipotezler ispatlanarak doğrulanır ya da çürütülür. $\mathrm{Bu}$ aşamanın sonunda oyun bağlamında hedef bilgiye sınıfın ulaşabileceği düşünülmektedir. Kurumsallaştırma aşamasında, sınıfın ulaştığı hedef bilgi farklı yollar ve örnekler üzerinden açıklanmaktadır. Ayrıca belirli bir bağlam kullanılarak elde edilen bilginin bağlamdan çıkarılarak bilgiye matematiksel derinlik kazandırılması da bu aşamada yapılmaktadır.

$\mathrm{Bu}$ çalışmada DDT çerçevesinde tasarlanan ortamın oluşturulmasında matematik tarihinden bir kesitten yararlanılmıştır. Matematik tarihinin öğretim ortamlarında kullanılmasının yansımalarına ilişkin literatürde birçok çalışma bulunmaktadır (Fried, 2001; Tzanakis, \& Arcavi, 2000). Bu çalışmalarda 1. Örneklerin yeniden yapılandırılması sürecinde yeni bir kavram, teori, yöntem veya kanıtı ögrenmek için motivasyon sağlamada ve derinlemesine anlamada, 2. Öğreten ve öğrenenlerin kendi araştırmalarını sürdürdüklerini düşünmelerini teşvik etmede, 3. Öğrenme motivasyonunu etkilemede ve öğretenlerin etkinliklerini zenginleştirmede, 4. Öğrenenlere matematiksel kuralların altında yatan prensiplerin öğretiminde matematik tarihinin etkili olarak kullanılabileceği belirtilmektedir (Baki, 2014; Fried, 2001; Tzanakis, \& Arcavi, 2000).

Literatürde matematik tarihinden alınan bir kesitin öğrenci merkezli bir ortamda öğretmen adaylarına öğretimine ya da tasarıma yönelik çok az sayıda çalışma olduğu belirlenmiştir. Bu bağlamda ilköğretim matematik öğretmen adaylarına Josephus problemini çözüm sürecinde matematiksel düşüncelerinin betimlenmesi (Çelik vd, 2015) ve karekök hesaplamada Babil metodunun tanıtılması 
(Karakuş, 2009) çalışmalarına yer verilebilir. Matematik tarihinin matematiksel bilginin öğretiminde zengin bir kaynak sunduğu ve matematiksel bilginin öğretimine yönelik problemlere çözüm bulunmasında alternatif yollar içerdiği belirtilebilir. Bu yüzden bu çalışmada matematik tarihinde yer verilen bir problem durumuna, kesirleri birim kesirlerin toplamı şeklinde yazabilmenin nasıl mümkün olacağına ilişkin genel bir yaklaşımın arandığı bir probleme, ilköğretim matematik öğretmen adaylarının çözüm yolu arayışları incelenmiştir. Bu doğrultuda aşağıdaki sorulara yanıtlar aranmaktadır:

- İlköğretim matematik öğretmen adayları öğrenci merkezli ortamda sunulan problem durumuna nasıl çözüm yolu geliştirmiştir?

- İlköğretim matematik öğretmen adaylarının problem durumuna yönelik çözüm yaklaşımlarında hangi modeller ortaya çıkmıştır?

- Öğrenci merkezli ortam tasarımlarında problem çözme sürecinde DDT'nin ilköğretim matematik öğretmen adaylarına hangi açılardan farkındalık sağlamış olabilir?

\section{Yöntem}

\subsection{Araştırma Modeli}

Bu çalışmada nitel araştırma yöntemlerinden durum çalışması kullanılmıştır. Merriam (2013) durum çalışmasını sınırlı bir sistemin derinlemesine betimlenmesi ve incelemesi olarak tanımlamıştır. $\mathrm{Bu}$ bağlamda lisans öğrenimlerinde öğrenci merkezli öğrenme ortamlarını teorik anlamda bilen, ancak bunları uygulamada henüz kullanma firsatı verilmeyen öğretmen adaylarına DDT çerçevesinde tasarlanan öğrenci merkezli bir etkinlik uygulanmıştır.

Etkinlik matematik tarihinden kesirlerin birim kesirleştirilmesine ilişkin bir metodun DDT’ye göre tasarlanan bir oyun ile öğretmen adaylarının etkileşimleri yoluyla öğretilecek şekilde tasarlanmıştır. Adidaktik durumlara uygun bir şekilde çalışmada problem durumu oyun içerisine gömülü bir şekilde sunulmuştur. Bu çalışmada kullanılan etkinlikteki oyunlar matematiksel oyun kategorisindedir.

Matematiksel oyun ile, matematiksel problemleri çözmek için kullanılan sürecin, fikir üretmek için hem deney hem de yaratıcılığı içeren ve bir tür sonuca varmak için herhangi bir fikri takip etmek için formel matematiğin kurallarını kullanma kastedilmektedir. Matematiksel oyun, durumun sınırlarını zorlamayı ve gidilebilecek her neresi varsa, oraya ulaşılarak fikir ve düşünceleri takip etmeyi içerir (De Holton vd, 2001).

\subsection{Araștırmanın Katılımcıları}

Araştırmanın katılımcılarını Doğu Anadolu bölgesinde bir devlet üniversitesinde öğrenim gören 21 (10 kız ve 11 erkek) ilköğretim matematik öğretmeni adayı oluşturmaktadır. Katılımcılar amaçlı örnekleme yöntemiyle belirlenmiştir. Amaçlı örnekleme yapılmasında araştırma konusuyla ilgili zengin veri elde etmek hedeflenmektedir (Yıldırım ve Şimşek, 2016).

\subsection{Problem Durumu}

\subsubsection{Kesirlerden Birim Kesirlere}

Bu oyun iki kişi ya da iki grup arasında oynanmaktadır. Oyunda amaç verilen basit kesirleri birim kesirlerin toplamı şeklinde yazmaktır. Ancak bu iş aşağıdaki koşullara uygun bir şekilde yapilmalıdır.

- Paydası küçük olan kesir önce gelmeli,

- İki kesir aynı olmamalı,

- Olabildiğince az sayıda birim kesir kullanılmalı. 
Sizce herhangi bir basit kesir birim kesirlerin toplamı şeklinde her zaman yazılabilir mi? Nasıl?

$$
\text { Örnek: } \frac{2}{3}=\frac{1}{2}+\frac{1}{6}
$$

\subsubsection{Oyunun Kurallart}

Öğretmen bir basit kesir verir. Bu kesri birim kesirlerin toplamı şeklinde açıklayan ilk grup 1 puan alır (birim kesirler tekrar etmeyecek). Eğer herhangi bir grubun bir basit kesrin birim kesirler olarak yazılımında verdiği çözüm ile ilgili gruplardan biri daha az sayıda birim kesir kullanılarak verilen kesri ifade edebilirse 2 puan verilecektir. Oyunun amacı bir basit kesri birim kesirlerin toplamı şeklinde ifade etmenin mümkün olup olmadığına ilişkin genel bir yolun varlığının araştırılmasıdır. Bu doğrultuda öğretmen adaylarına kolaydan zora olacak şekilde bazı kesirler verilerek $(2 / 5,2 / 7,2 / 9,9 / 13$ gibi) onları birim kesirlerin toplamı olarak yazmaları istenmiştir.

Bu problem durumu, öğretmen adaylarına Eski Mısırda 0 ile 1 arasında rasyonel bir kazanç elde eden sonlu sayıdaki işçilerin elde ettikleri kazancı paylaşmaları (eşit paylaşma kastedilmiyor) bağlamında sunulmuştur. Doğal olarak bu paylaşım verilen kesrin birim kesirler yoluyla paylaştırılmasını gerektirmektedir. Matematik tarihinde bu problemin ayırma yöntemi (splitting method) ve Fibonacci yöntemi olarak iki genel yaklaşımla çözülmesi mümkündür (Burton, 2011). Öğretmen adaylarının bu yöntemlere ya da daha lokal yöntemlerden hangilerine ulaşabilecekleri ve bu süreçte ortamın betimlenmesi bu çalışma kapsamında incelenmiştir.

\subsection{Veri Toplama Araçları, Verilerin Düzenlenmesi ve Uygulama Süreci}

Çalışmanın verileri video kamera, ses kayıt cihazları ve alan notları aracılığıyla (etkinlik öncesi dağıtılan A4 kağıtları, fotoğraflar gibi) toplanmıştır. Veriler tekrar dinleme yoluyla bilgisayar ortamına aktarılmıştır. Daha sonra verilerin çözümlenmesine geçilmiştir.

\subsection{Etkinliği Uygulama Süreci}

Bu çalışma uygulama süreci iki alt bölümden oluşmaktadır. Birincisi tasarım ve diğeri uygulamadır. Tasarım alt başlığı 1 . Öğretmen adaylarına uygun matematik tarihinden bir problemin belirlenmesi, 2. Bu problemin DDT'nin temel bileşenlerinden adidaktik durumlar kapsamında uyarlanması, 3. Pilot çalışmasının yapılması süreçlerini barındırmaktadır. Pilot çalışma ilköğretim matematik öğretmenliği mezunu dört öğretmen ile gerçekleştirilmiştir. Pilot çalışmada problemin koşullarının daha açık sunulması gerektiği anlaşılmıştır. Bu doğrultuda iki koşula sahip problemdeki koşullar üçe çıkarılarak öğretmen adaylarına sunulması kararlaştırılmıştır. Gerekli düzenlemeler yapıldıktan sonra asıl uygulama gerçekleştirilmiştir.

Asıl uygulama 76 dakika sürmüştür. Bu uygulama 21 öğretmen adayı ile gerçekleştirilmiştir. Uygulama süreci öncesinde öğretmen adayları birinci grup 11 ve diğeri 10 olacak şekilde iki gruba ayrılmıştır. Bu gruplar verilen 0 ile 1 arasındaki rasyonel sayıyı birim kesirlerin toplamı olarak yazması istenmiştir. Bu doğrultuda ilk doğru yanıta 1 puan verilmiş, doğru yanıtta daha az birim kesir kullanan gruba ise 2 puan verilmiştir. Bulgularda grup 1'deki öğretmen adayları Ö1, Ö3,..., Ö21 şeklinde tek sayılarla ve grup 2'deki öğretmen adayları Ö2, Ö4,.., Ö20 şeklinde çift sayılarla temsil edilmiştir. Bulgularda etkinliği organize eden araştırmacı A olarak kodlanmıştır.

\subsection{Verilerin Analizi}

Veriler DDT'nin farklı aşamalarında öğretmen adaylarının ortaya koyduğu yaklaşımları betimlenmesi yoluyla gerçekleştirilmiştir. Bu doğrultuda veriler Tablo 1'de belirtilen aşamalar doğrultusunda çözümlenmiştir. 
Tablo 1: Verileri DDT’nin Aşamaları Doğrultusunda Çözümlenme

\begin{tabular}{|c|c|}
\hline Aşamalar & Aşamalarda Roller \\
\hline \multirow[t]{2}{*}{ Sorumluluk Aktarma } & $\begin{array}{l}\text { Öğrenci: Oyunun kurallarını anlama, Oyunu bağımsız oynayabilecek duruma } \\
\text { erişme }\end{array}$ \\
\hline & $\begin{array}{l}\text { Ögrretmen: Ortamını hazırlama, Materyalleri belirtme, Oyunun tanıtılması ve } \\
\text { kurallarının açıklanması, Öğretmen ve öğrenci rollerini açıklama }\end{array}$ \\
\hline \multirow[t]{2}{*}{ Eylem } & $\begin{array}{l}\text { Öğrenci: Oyun oynamaya istekli olma, Grup içi tartışmalarda aktif olma, Gruplar } \\
\text { arası oyuna katılma, Stratejiler sunma, Rakibin stratejilerini anlamaya çalışma, } \\
\text { Kendi stratejilerini revize etme }\end{array}$ \\
\hline & $\begin{array}{l}\text { Ö̆gretmen: Ortamın dinamik yapısını organize etme, Oyun bağlamını teşvik } \\
\text { etme, Oyunla ilgili yanlış anlaşılmaları düzeltme, Grup içi tartışmaya yöneltme, } \\
\text { Gruplar arası iletişimi organize etme, Çözüme yönelik ipuçları vermekten } \\
\text { kaçınma }\end{array}$ \\
\hline \multirow[t]{2}{*}{ İfade Etme } & $\begin{array}{l}\text { Ögrenci: Hipotezler üretme, Rakip grubun hipotezlerini inceleme, Bir model } \\
\text { ortaya koyma }\end{array}$ \\
\hline & $\begin{array}{l}\text { Öğretmen: Grup içi tartışmaya teşvik, Hipotezlerin sınıf ortamına sunulmasını } \\
\text { sağlama, Hipotezleri herkesin anlaşılmasını sağlama }\end{array}$ \\
\hline \multirow[t]{2}{*}{ Doğrulama } & $\begin{array}{l}\text { Öğrenci: Grubun hipotezini savunma, Rakip grupların hipotezlerini çürütmeye } \\
\text { çalışma, Açıklama yapma, ispat yapma, Sınıf tartışmasına aktif katılım }\end{array}$ \\
\hline & $\begin{array}{l}\text { Öğretmen: Hipotezlerin tartışılmasını teşvik etme, Gruplara sunulan hipotezleri } \\
\text { savunma ya da çürütme imkanı sunma, Sınıf tartışmasını organize etme }\end{array}$ \\
\hline \multirow[t]{2}{*}{ Kurumsallaştırma } & $\begin{array}{l}\text { Öğrenci: Oyundaki hedef bilgiyi anlama, Hedef bilginin gerçek yaşamda } \\
\text { kullanımlarına ilişkin tahminler yapma }\end{array}$ \\
\hline & $\begin{array}{l}\text { Öğretmen: Oyun bağlamında hedef bilgiyi tekrar açıklama, Oyunu kazandıran } \\
\text { farklı stratejilere yer verme, Hedef bilginin günlük yaşamdaki kullanımlarını } \\
\text { belirtme, Oyun bağlamında üretilen hedef bilgiye matematiksel anlam } \\
\text { kazandırma }\end{array}$ \\
\hline
\end{tabular}

Tablo 1'den anlaşılacağı üzere, etkinliklerin uygulanmasına ilişkin DDT'de yer verilen aşamalar incelendiğinde öğrenci merkezli bir öğrenme ortamının oluşturulmaya çalışıldığı görülmektedir. $\mathrm{Bu}$ aşamalarda öğretmen ve öğrenci davranışları Tablo 1'de ayrıntılı bir şekilde betimlenmiştir.

Bu çalışmada amaç DDT çerçevesinde tasarlanan bir ortamda ilköğretim matematik öğretmen adaylarının DDT'nin farklı aşamalarında ortaya koydukları yaklaşımları betimlemek olduğundan analizler Tablo 1'de verilen göstergeler aracılığıyla gerçekleştirilmiştir. Bu tür çalışmalarda asıl amaç, incelenen durumu etraflıca tanımlamak ve açıklamaktır (Çepni, 2009). Bu doğrultuda bulgular bölümünde ilgili aşamanın betimlenmesinde doğrudan alıntılara yer verilmektedir.

\section{Bulgular}

Bu bölümde ilköğretim matematik öğretmeni adaylarına DDT çerçevesinde tasarlanan etkinlikte matematik tarihinden uyarlanan bir problem durumuna DDT'nin farklı aşamaları dikkate alınarak çözüm aramışlardır. Bu bağlamda çalışma kapsamında ilk iki soruya DDT'nin farklı aşamalarında aşağıda yanıt verilmiştir. Üçüncü soru ise bu aşamalarda öğretmen adaylarının öğrenci merkezli etkinliğin kriterlerine uygun hareket tarzı çerçevesinde ve etkinlik sonrası yapılan kısa görüşlerinin alınması yoluyla yanıtlanmıştır. 


\subsection{Sorumluluk Aktarma Aşaması}

Öğretmen uygulamanın başında etkinliği, etkinliğin amacını, etkinlikte kullanılan problem durumunu, bu problem durumuna öğretmen adaylarının nasıl yanıt araması gerektiğini ve değerlendirmenin nasıl yapılacağını aşağıda verildiği şekliyle belirtmiştir.

A: Bu gün bir etkinlik yapacağız. Etkinliğimizin amacı şu, yapılandırmacı yaklaşıma uygun ortamlarda arkadaşlar öğrenme nasıl sağlanır?..., bir şeyin doğru olup olmadığına siz karar veriyorsunuz. ... oyunu anlatacağım ben size... Eski Misırda ne vardı? Birim kesirler vardı, değil mi? ...Eski Mısırlılar nasıl yapıyormuş da 0 ile 1 arasındaki rasyonel sayıları birim kesirlere dönüştürüyormuş arkadaşlar... Ben size 0 ile 1 arasındaki rasyonel sayıları vereceğim... Gruplara belli bir süre vereceğiz arkadaşlar... Oyunda amaç verilen basit kesirleri veya 0 ile 1 arasındaki rasyonel sayıları arkadaşlar, birim kesirlerin toplamı şeklinde yazmak... İlk söyleyen 1 puan alır... üç tane kritere dikkat etmenizi isteyeceğim arkadaşlar... Birinci maddemiz paydası küçük olan kesirler önce gelmeli. İkinci kriterimiz iki kesir aynı olmamalı. Yani siz 2/3 ü arkadaşlar 1/3 + 1/3 şeklinde yazarsanız bu cevabi kabul etmiyoruz.

Ö2: Anladık hocam tekrar kullanmıyoruz.

A:Olabildiğince de az sayıda kesir kullanacaksınız.

$\mathrm{Bu}$ açıklamalarda görüleceği üzere, öğretmen etkinliğin öğrenci merkezli bir ortamda nasıl uygulanması gerektiğine ilişkin açıklamalar yapmıştır. Burada grupların bulduğu bir çözümün yine kendileri tarafından doğru ya da yanlış olduğuna karar vermeleri gerektiği belirtilmiştir. Bu bağlamda öğretmen adaylarına basit kesirler vermiş ve bunları birim kesirlerin toplamı olarak belirtmelerini istemiştir. Ayrıca bu süreçte dikkat etmeleri gereken koşullar ve sınırlılıklar da açıklanmıştır.

Öğretmen adaylarının problemin çözümünde daha aktif katılımını sağlamak için, bir yarışma dizayn ederek, problemin grup içinde ve gruplar arasında etkileşim sürecinde çözülebileceği bir ortam oluşturmaya çalışmıştır. Bu doğrultuda yarışmada değerlendirmenin rakibi ikna ederek yapılacağını belirtmiş ve grupların bu yolla puan kazanacaklarını açıklamıştır. Puanlamada doğru çözümlere 1 puan verileceği açıklanmıştır. Bununla birlikte birden fazla doğru çözüm olduğunda daha az birim kesrin kullanıldığı grup 2 puan alacağı belirtilmiştir. Dolayısıyla çözümler oluşturulurken verilen basit kesrin daha az sayıda birim kesirlerin toplamı şeklinde ifade edilmesi gerektiği anlaşılmaktadır. Sonrasında rastgele bir öğretmen adayını seçerek, problemi tekrar açıklamasını istemiştir. Bu açıklamalardan sonra öğretmen adaylarının oyunu anladığı görülmüştür. Sorumluluk aktarma aşaması 13 dakika sürmüştür.

\subsection{Eylem, İfade Etme ve Doğrulama Aşamaları}

Eylem, ifade etme ve doğrulama aşamaları adidaktik aşamalar olması sebebi ile birlikte verilmesinin daha uygun olduğu belirtilebilir. Bunun diğer bir nedeni bu çalışmada verilen her basit kesir için bu süreçlerin genellikle iç içe geçmesi olarak açıklanabilir. Bu aşamalarda iki gruba ayrılan sınıfa, öğretmen basit kesirler vermiş ve bu basit kesirleri birim kesirlerin toplamı şeklinde yazmalarını istemiştir. $\mathrm{Bu}$ sayede eylem aşaması başlamıştır. Eylem aşamasında yarışma bağlamında gruplar arasında oynanan oyunlara ilişkin sonuçlar Tablo 2'de verilmiştir. 
Tablo 2: Öğretmen Adaylarının Eylem, İfade Etme ve Doğrulama Aşamalarındaki Oyun Süreçleri

\begin{tabular}{|c|c|c|c|c|c|}
\hline Oyun & Oyuncu & Verilen Kesir & Birim Kesirleştirilmesi & Süreç & Onay/Ret \\
\hline $\mathbf{1}$ & Ö2 & $2 / 5$ & $1 / 5+1 / 10$ & 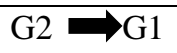 & Ret \\
\hline 2 & Ö3 & $2 / 5$ & $1 / 5+3 / 10$ & $\mathrm{G} 1 \Rightarrow \mathrm{G} 2$ & Ret \\
\hline 3 & Ö5 & $2 / 5$ & $1 / 5+1 / 20$ & $\mathrm{G} 1 \Rightarrow \mathrm{G} 2$ & Ret \\
\hline 4 & Ö7 & $2 / 5$ & $1 / 3+1 / 15$ & $\mathrm{G} 1 \Rightarrow \mathrm{G} 2$ & Onay \\
\hline 5 & Ö8 & $2 / 7$ & $1 / 4+1 / 28$ & $\mathrm{G} 2 \overrightarrow{\mathrm{G} 1}$ & Onay \\
\hline 6 & Ö9 & $2 / 7$ & $1 / 7+1 / 14+1 / 21$ & $\mathrm{G} 1 \Rightarrow \mathrm{G} 2$ & Ret \\
\hline 7 & Ö8 & $2 / 7$ & $1 / 7+1 / 14+1 / 21+1 / 42$ & $\mathrm{G} 2 \Rightarrow \mathrm{G} 1$ & Ret \\
\hline 8 & Ö11 & $2 / 9$ & $1 / 5+1 / 45$ & $\mathrm{G} 1 \Rightarrow \mathrm{G} 2$ & Onay \\
\hline 9 & Ö4 & $2 / 9$ & $1 / 9+1 / 18+1 / 27+1 / 81$ & $\mathrm{G} 2 \Rightarrow \mathrm{G} 1$ & Ret \\
\hline 10 & Ö3 & $2 / 9$ & $1 / 9+1 / 18+1 / 27+1 / 54$ & $\mathrm{G} 1 \Rightarrow \mathrm{G} 2$ & Onay \\
\hline 11 & Ö6 & $2 / 9$ & $1 / 6+1 / 18$ & $\mathrm{G} 2 \Rightarrow \mathrm{G} 1$ & Onay \\
\hline 12 & Ö3 & $2 / 11$ & $1 / 6+1 / 66$ & $\mathrm{G} 1 \Rightarrow \mathrm{G} 2$ & Onay \\
\hline 13 & Ö3 & $2 / 11$ & $1 / 11+1 / 22+1 / 33+1 / 66$ & $\mathrm{G} 1 \Rightarrow \mathrm{G} 2$ & Onay \\
\hline 14 & Ö2 & $3 / 4$ & $1 / 2+1 / 4$ & $\mathrm{G} 2 \Rightarrow \mathrm{G} 1$ & Onay \\
\hline 15 & Ö6 & $3 / 4$ & $1 / 2+1 / 6+1 / 12$ & $\mathrm{G} 2 \overrightarrow{\mathrm{G} 1}$ & Onay \\
\hline 16 & Ö7 & $3 / 4$ & $1 / 2+1 / 3+1 / 6+1 / 12$ & $\mathrm{G} 1 \Rightarrow \mathrm{G} 2$ & Ret \\
\hline 17 & Ö3 & $3 / 5$ & $1 / 5+1 / 15$ & $\mathrm{G} 1 \overrightarrow{\mathrm{G} 2}$ & Ret \\
\hline 18 & Ö6 & $3 / 5$ & $1 / 2+1 / 10$ & $\mathrm{G} 2 \overrightarrow{\mathrm{G} 1}$ & Onay \\
\hline 19 & Ö17 & $3 / 5$ & $1 / 3+1 / 5+1 / 15$ & $\mathrm{G} 1 \Rightarrow \mathrm{G} 2$ & Onay \\
\hline 20 & Ö12 & $3 / 8$ & $1 / 4+1 / 8$ & $\mathrm{G} 2 \overrightarrow{\mathrm{G} 1}$ & Onay \\
\hline 21 & Ö3 & $3 / 8$ & $1 / 3+1 / 24$ & $\mathrm{G} 1 \overrightarrow{\mathrm{G} 2}$ & Onay \\
\hline 22 & Ö2 & $3 / 10$ & $1 / 4+1 / 20$ & $\mathrm{G} 2 \Rightarrow \mathrm{G} 1$ & Onay \\
\hline 23 & Ö14 & $3 / 10$ & $1 / 5+1 / 10$ & $\mathrm{G} 2 \Rightarrow \mathrm{G} 1$ & Onay \\
\hline 24 & Ö4 & $4 / 5$ & $1 / 4+1 / 20$ & $\mathrm{G} 2 \overrightarrow{\mathrm{G} 1}$ & Ret \\
\hline 25 & Ö13 & $4 / 5$ & $1 / 5+1 / 20$ & $\mathrm{G} 1 \overrightarrow{\mathrm{G} 2}$ & Ret \\
\hline 26 & Ö15 & $4 / 5$ & $1 / 2+1 / 5+1 / 15$ & $\mathrm{G} 1 \overrightarrow{\mathrm{G} 2}$ & Ret \\
\hline 27 & Ö15 & $4 / 5$ & $1 / 2+1 / 5+1 / 10$ & $\mathrm{G} 1 \overrightarrow{\mathrm{G} 2}$ & Onay \\
\hline 28 & Ö15 & $4 / 5$ & $1 / 5+1 / 3+1 / 5+1 / 15$ & $\mathrm{G} 1 \Rightarrow \mathrm{G} 2$ & Ret \\
\hline 29 & Ö16 & $9 / 13$ & $1 / 13+1 / 104$ & $\mathrm{G} 2 \overrightarrow{\mathrm{g} 1}$ & Ret \\
\hline 30 & Ö3 & $9 / 13$ & $1 / 13+1 / 39$ & $\mathrm{G} 1 \Rightarrow \mathrm{G} 2$ & Ret \\
\hline 31 & Ö7 & $9 / 13$ & $1 / 2+1 / 7+1 / 13+1 / 26+1 / 91$ & $\mathrm{G} 1 \Rightarrow \mathrm{G} 2$ & Ret \\
\hline 32 & Ö3 & $9 / 13$ & $1 / 13+1 / 39+1 / 78$ & $\mathrm{G} 1 \overrightarrow{\mathrm{G}} 2$ & Ret \\
\hline 33 & Ö4 & $9 / 13$ & $1 / 2+1 / 13+1 / 26+1 / 39+1 / 78$ & $\mathrm{G} 2 \Rightarrow \mathrm{G} 1$ & Ret \\
\hline 34 & Ö4 & $9 / 13$ & $1 / 2+1 / 6+1 / 39$ & $\mathrm{G} 2 \Rightarrow \mathrm{G} 1$ & Onay \\
\hline 35 & Ö18 & $10 / 13$ & $1 / 2+1 / 6+1 / 13+1 / 39$ & $\mathrm{G} 2 \overrightarrow{\mathrm{G} 1}$ & Onay \\
\hline 36 & Ö4 & $10 / 13$ & $1 / 2+1 / 4+1 / 52$ & $\mathrm{G} 2 \overrightarrow{\mathrm{G} 1}$ & Onay \\
\hline
\end{tabular}

Tablo 2'den, öğretmen adaylarının kendilerine verilen basit kesirlerin tamamını en az bir yolla birim kesirlerin toplamı şeklinde yazabildikleri görülmektedir. Bu süreçte gruplar arasında (grup 1'den grup 2'ye ya da grup 2'den grup 1'e doğru) birçok etkileşim olduğu tespit edilmiştir. Bu doğrultuda 
herhangi bir basit kesrin birim kesirlerin toplamı şeklinde bir grubun ortaya attığı iddiayı (ya da yanıtı) diğer grubun doğrulama (onay ya da ret) pozisyonunda olduğu anlaşılmaktadır. Yani etkinlikte eylem aşaması ve doğrulama aşaması birlikte gerçekleşmiştir. Bu süreçler gruplar arasında yoğun bir etkileşim olduğunu resmetmektedir. $\mathrm{Bu}$ oyunlarda verilen basit kesirlerin birim kesirlerin toplamı şeklinde yazılması sürecinde kolaydan zora doğru bir yol izlendiği görülmektedir. İlk oyunlarda ret oranının daha yüksek olduğu görülmektedir. Bu durum öğretmen adaylarının oyuna tam angaje olamamalarıyla açıklanabilir. Onuncu oyundan itibaren yirmi üçüncü oyuna kadar olan süreçte öğretmen adaylarının oyuna adapte oldukları ve genellikle doğru çözümler ürettikleri belirlenmiştir. Bu durum problem durumuna ilişkin örtük çözüm stratejilerinin fark edildiğini göstermektedir. Nitekim 10 ve 13. oyunlarda Ö3 kodlu öğretmen adayının çözüm stratejisinin benzer olduğu görülmektedir. Burada öğretmen adayının $2 / n=1 / n+1 / 2 n+1 / 3 n+1 / 6 n$ stratejisini kullandığı anlaşılmaktadır. Sonraki oyunlar daha zor düzeylerde incelendiğinden öğretmen adaylarının verdiği yanıtlarda ret oranı fazla olmakla birlikte verilen basit kesirler birim kesirlerin toplamı şekilde en az bir yolla yazılmıştır.

Tablo 2'de dikkat çeken diğer bir önemli nokta, verilen bir kesri birim kesirlerin toplamı şeklinde yazma sürecinde öğretmen adaylarının birden fazla çözüm yolu arayış gayretidir. Öğretmen adaylarına sunulan basit kesirlerin yaklaşık üçte ikisinin, verilen basit kesirlerin birim kesirlerin toplamı şeklinde yazımında birden çok çözüm yolu geliştirilmiştir. Örneğin $2 / 9=1 / 5+1 / 45=1 / 9+1 / 18+1 / 27+1 / 54=1 / 6+1 / 18$ biçiminde üç farklı şekilde birim kesirlerin toplam1 şeklinde ifade edilmiştir. Tasarlanan etkinliğin yarışma bağlamında sunulması, ortamda grupların daha fazla puan kazanmak istemeleri ve problemlerin çoklu yolların kullanımı için uygun seçilmesinin çoklu çözüm yollarının ortaya çıkmasında etkili olduğu belirtilebilir. Şekil 1'de öğretmen adaylarının etkinlik boyunca karşılaştıkları oyunları kazanma ve kaybetme durumları verilmiştir.

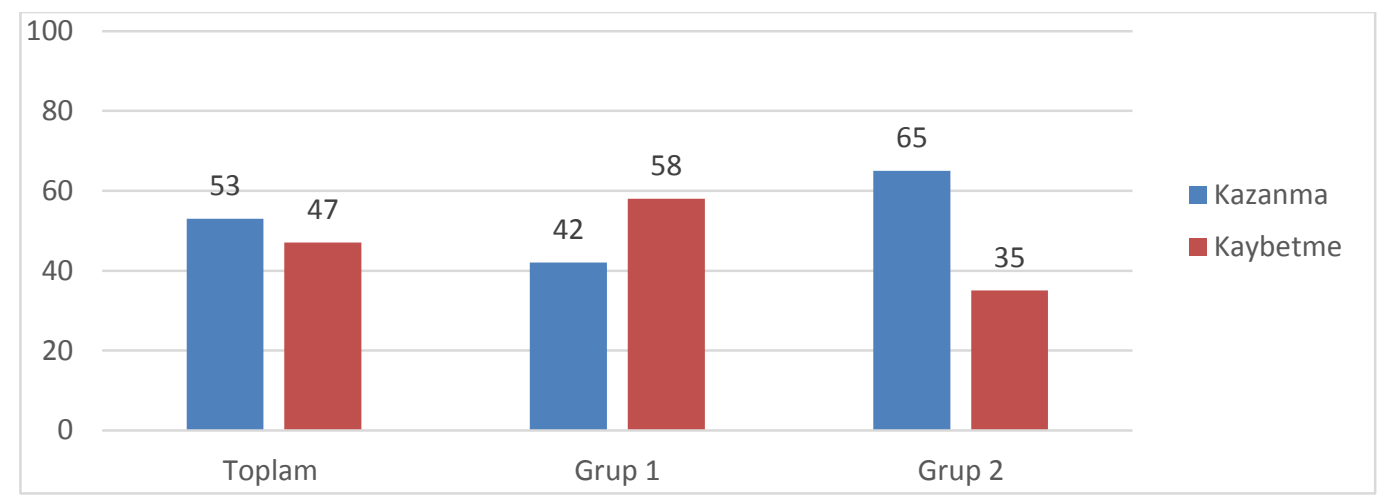

Şekil 1. Öğretmen Adaylarının Oyunları Kazanma-Kaybetme Durumları

Şekil 1'de görüldüğ̈̈ üzere, etkinlik süresince oynanan oyunlarda öğretmen adaylarının verdikleri çözümlerin yarısından fazlasının doğru olduğu belirlenmiştir. Grup bazında bu oran incelendiğinde grup 2'nin verdiği yanıtların grup 1'den daha yüksek olduğu anlaşılmaktadır. Öğretmen adaylarının kazanma ve kaybetme durumlarına ilişkin Tablo 2'de verilen 20 ve 21 . oyunlar aşağıda betimlenmiştir.

Ö12: Hocam söyleyebilir miyim?1/4 artı 1/8.

A : $1 / 4$ art1 1/8. Grup 2 verdi bunu. Grup 1 kat1liyor mu?

Ö1 : Doğru hocam (Grup 1'den bir öğrenci onayladı).

Ö3 : (Diğer gruptan da bir cevap geldi) Hocam 1/3+1/24.

A : İki çözümde de iki tane birim kesir olduğu için birer puan.

Ö3 : Bizimki daha güzel bir şekil oldu.

A : Arkadaşımız diyor ki, bizimki daha güzel oldu. Neden daha güzel olduğunu düşündün? 
Ö3 : Hocam çünkü bizimkinde teorem (strateji ya da metot) var. Onlarınki, rastgele oldu.

A : Teorem var diyorsunuz. O zaman bundan sonra şöyle yapalım. Artık, hipotezinizi verin, tamam mı? Stratejiniz varsa, onu da açılayın arkadaşlar.

Diyalogda belirtildiği üzere, Ö3 kodlu öğretmen adayı verilen basit kesirleri rastgele birim kesirlerin toplamı şeklinde yazmadığını belli bir metodu olduğunu ifade etmiştir. Bu doğrultuda öğretmen artık verilen çözümler ile birlikte belirli bir metot kullanılmışsa onlarında açıklanmasını istemiştir. Bu sayede basit kesirlerin birim kesirlerin toplamı şeklinde yazılmasına yönelik genel kuralların ortaya çıkmasına ilişkin teşvik edici bir yaklaşım sunulmuş ve bu anlamda tartışmaların başlamasına ilişkin ortam organize edilmiştir. Dolayısıyla bundan sonraki süreçte eylem, ifade etme ve doğrulama aşamalarının birlikte gerçekleştiği bir ortam ortaya çıkmıştır. Bu ortamda öğretmen adayları bir yandan verilen basit kesri birim kesirlerin toplamı olarak belirtecekler, diğer yandan bu süreçte belirli bir metot kullanmışlarsa açıklayacaklardır. Ayrıca kullanılan metodun ne ölçüde doğru sonuçlar verdiğini tartışacaklardır. Öğretmen adaylarının etkinlik boyunca sunulan problemlerin çözümüne yönelik geliştirdikleri metotlar (hipotezler) Tablo 3’te verilmiştir.

Tablo 3: Öğretmen Adaylarının Geliştirdiği Metotlar

\begin{tabular}{|c|c|c|c|}
\hline No & Oyuncu & Sunulan Hipotezler ve Doğrulanma Süreci & Model \\
\hline 1 & Ö15 & $\begin{array}{l}\text { Ö15: } 1 / 5+1 / 2+1 / 10 \\
\text { A: } 4 / 5=1 / 2+1 / 5+1 / 10 \text { Neden böyle bir şey verdin? Nasıl } \\
\text { verdin bunu? Stratejin var mı? } \\
\text { Ö15: Haa şey } 1 / 5 \text { artı } 3 / 5 \text { 'ten }(1 / 5+3 / 5=4 / 5 \text { eder) } 3 / 5 \text { 'i zaten } \\
\text { önceden bulmuşuz ( } 6 \text {. oyunda } 3 / 5=1 / 2+1 / 10 \text { olarak } \\
\text { bulunmuştu). }\end{array}$ & $x / n=(x-a) / n+a / n$ \\
\hline 2 & Ö11 & $\begin{array}{l}\text { Ö11: İlk verdiğiniz örnek ne idi? } \\
\text { A: } 2 / 5=1 / 3+1 / 15 \\
\text { Ö11: Aynen. } 1 / 3+1 / 15,2 / 5 \text { 'te } 1 / 3 \text { 'ü alıyoruz. Sonra } 5 \text { ile } 3 \text { 'ü } \\
\text { çarpiyoruz diğer birim kesrin paydasını veriyor. Hocam } \\
\text { mesela bir sonraki adımda } 2 / 7 \text { dediniz. Ben dedim ee şöyle } \\
\text { olur hocam. } 1 / 3 \text { (karar değiştirdi) pardon } 1 / 4+1 / 28 \text { olur. } \\
\text { A: } 1 / 4 \text { 'ü nerden buldun? } \\
\text { Ö11: Hocam ritmik olarak devam ediyor. } \\
\text { Ö5: Devam ediyor aritmetik olarak. } \\
\text { Ö11: Şunlarla çarpım halinde. Aynı şekilde } 2 / 9 \text { da da devam } \\
\text { ediyor. İkililerde böyle yaptı. }\end{array}$ & $2 /(2 n-1)=1 / n+1 / n(2 n-1)$ \\
\hline 3 & Ö11 & $\begin{array}{l}\text { Ö11: ...hocam mesela 1/11+1/22+1/33+1/66 olanı ele alalım. } \\
\text { A: } 2 / 11 \text { ne imiş? } \\
\text { Ö11: Hocam } 2 / 11 \text { ee şunu paydayı yazıyorum aynı şekilde. } \\
\text { Hocam } 2 \text { katı, } 3 \text { katı sonra } 6 \text { katı yapılınca sağlıyor. Mesela } \\
\text { hocam } 2 / 13 \text { için de denedim. O da sağlıyor. } \\
\text { Ö5: Sonra } 6 \text { katı } \\
\text { A: H11, } 1 / 11 \text { aynen yazdın. Sonra paydanın } 2 \text { katı, } 3 \text { katı, } 6 \\
\text { katı olan birim kesir olacak şekilde yazıldı̆ında eşit olduğunu } \\
\text { ifade ediyorsun. Genelleştirirsek ne dersin metoduna? } \\
\text { Ö11: Hocam } 2 / n=1 / n+1 / 2 n+1 / 3 n+1 / 6 n\end{array}$ & $2 / n=1 / n+1 / 2 n+1 / 3 n+1 / 6 n$ \\
\hline 4 & Ö4 & $\begin{array}{l}\text { Ö4: Çok basit bir şey var. Ee bütün hepsini çözebiliyorum } \\
\text { artık. } \\
\text { A: Hı̈, söyle. } \\
\text { Ö4: Mesela } 10 / 13 \text { 'ü alalım. Bunun içindeki birim kesirlerden } \\
\text { en büyüğünü ç1karıyorum. } 1 / 2 \text { ç1karmalıyım. Ee ne kald } \\
\text { geriye? } 10 / 13-1 / 2=7 / 26 \text { Şimdi bunun içindeki en büyük birim } \\
\text { kesir } 1 / 4 \text {. Şimdi } 52 \text { 'de birleşiyor. } 7 / 26-1 / 4=1 / 52 \text {. Zaten geriye } \\
1 / 52 \text { kaldı. O zaman } 10 / 13=1 / 2+1 / 4+1 / 52 \text { eşittir. }\end{array}$ & $\begin{array}{l}\text { Fibonacci Metodu (Bkz. } \\
\text { Burton, 2011). }\end{array}$ \\
\hline
\end{tabular}

Turkish Studies - Educational Sciences

Volume 14 Issue 5, 2019 
Tablo 3’te görüleceği üzere, etkinlik boyunca ilköğretim matematik öğretmen adaylarının 0 ile 1 arasındaki rasyonel sayıların birim kesirlerin toplamı biçiminde ifade edilmesine ilişkin 4 farklı yol geliştirdiği belirtilebilir. Bunlardan ilki deneme-yanılma ve önceki oyunlardan yararlanılarak elde edildiği görülmektedir. Bu bağlamda pragmatik ve semantik orijinli (Brousseau, 1997) olduğu belirtilebilir. Ö11 kodlu öğretmenin ortaya attığ 2 ve 3 numaralı metotlar ise pay1 2 olan kesirlerin birim kesirlerin toplamı olarak yazılmasında etkili olarak kullanılabileceğinden local çözüm yolları olarak belirtilebilir. Ancak Ö4 kodlu öğrencinin sunduğu Fibonacci metoduna yakın bir açıklamayla artık herhangi bir birim kesri öğretmen adaylarının birim kesirlerin toplamı biçiminde yazmanın yolunun bilinir kılındığı belirtilebilir.

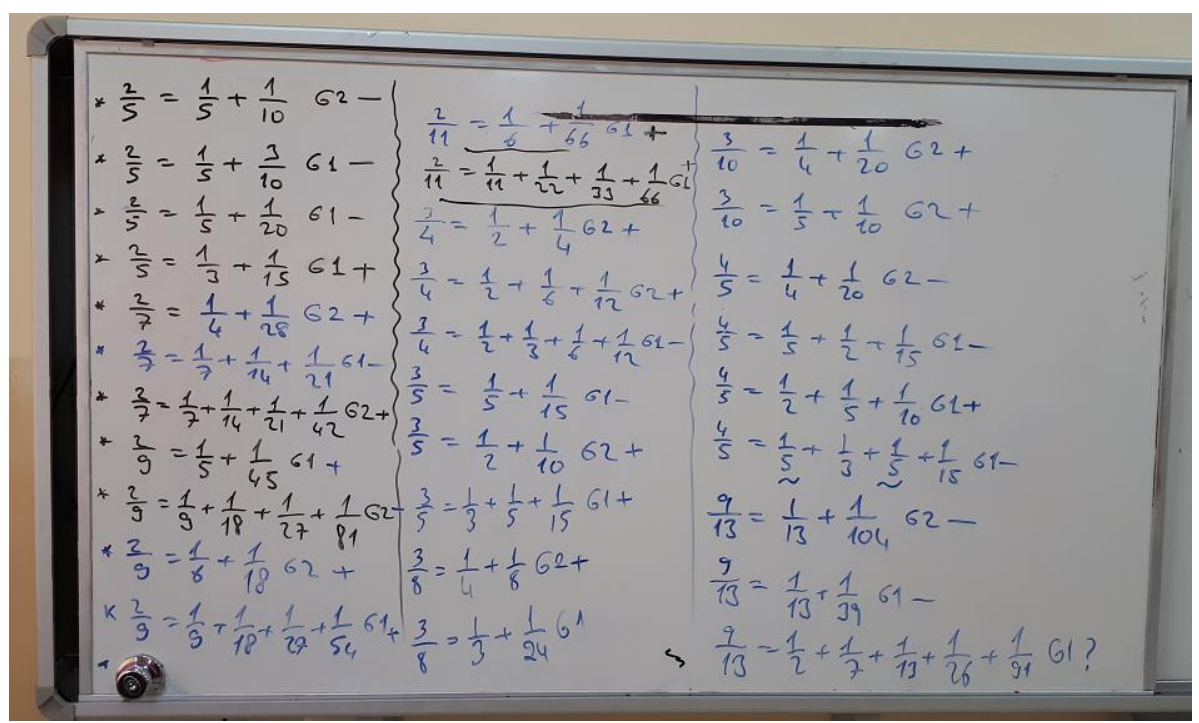

Şekil 2. Adidaktik Aşamalarda Grupların Problem Durumuna İlişkin Ürettiği Çözümler

Etkinlik sürecinde grup içi ve gruplar arası etkileşimin incelenmesi araştırmada bazı bilinmeyen noktaları ortaya çıkarabilir. Örneğin Tablo 2'de Ö3 kodlu öğretmen adayının 10 ve 13. oyunlarda örtük olarak kullandığı metodu Ö11 kodlu öğretmen adayı Tablo 3'te açıkça ortaya koymuştur. Bu durum grup içi etkileşimde bilginin bireyler arasında paylaşıldığını göstermektedir. Yani grup çalışmasının belli ölçüde gerçekleştirildiği belirtilebilir. Diğer taraftan araştırmanın geneli incelendiğinde bazı öğretmen adayının bireysel gayretlerinin diğerlerine göre daha ön planda olduğu gözlenmektedir. Örneğin Ö3, Ö11 ve Ö4 kodlu öğretmen adayları bu bağlamda değerlendirilebilir. Bu da gerçekleştirilen etkinlikte bireysel çalışmanın da desteklendiğini göstermektedir. Ö4 kodlu öğretmen adayının geliştirdiği metodu bulma sürecinde düşünsel yaklaşımı aşağıda verilmiştir.

A : Bu yöntemi nasıl buldun?

Ö4: Hocam sistematik gitmeye çalıştım ve daha çok genel bir metot yani her zaman geçerli bir metot aradım. Aslında etkinliğin başında çok istekli değildim. Ancak sonrasında hoşuma gitti, çözüm bulmak için çabaladım. Sonrasında da buldum.

A : Bu problemi ya da metodu daha önce duydun mu?

Ö4: Hayır, ilk kez burada karşılaştım.

$\mathrm{Bu}$ açıklamalardan etkinlik tasarımının öğretmen adaylarının etkinliğe katılımını desteklediği ve bunda öğrenci merkezli ortam tasarımının etkili olduğu belirtilebilir. Yine sistematik yaklaşıldığında ve problemdeki koşullar dikkate alındığında problemlere genel çözüm yollarının bireysel olarak üretilebileceği ifade edilebilir. Adidaktik aşamalar olarak belirtilen bu aşamalar (eylem, ifade etme ve doğrulama) toplam 50 dakika sürmüştür. 


\subsection{Kurumsallaştırma Aşaması}

$\mathrm{Bu}$ aşamada 0 ile 1 arasında verilen rasyonel sayıları öğretmen adaylarının birim kesirlerin toplamı biçiminde yazma sürecinde geliştirdikleri yollar öğretmen tarafindan açıklanmıştır. $\mathrm{Bu}$ bağlamda Tablo 3'de verilen modellerin sonlu sayıda iterasyonun gerçekleştirildiğinde verilen herhangi bir kesrin basit kesirlerin toplamı olarak yazılabileceği belirtilmiştir. Bu doğrultuda öğretmen Fibonacci metodu bağlamında bir örnek daha uygulayarak etkinliği tamamlamıştır.

A : Herhangi bir basit kesir alalım. Mesela 7/15 olsun. Bunu ters çeviriyorsunuz. Ters çevirince ne oldu? 15/7 oldu. Bu hangi sayılar arasında 2 ile 3 arasındadır. Bunu elde ettikten sonra büyük olan tamsayıyı birim kesrin paydasına yazarak ilk kesirden çıkarıyoruz. Yani 7/15-1/3=2/15 kaldı. Bunu ters çevirelim. 15/2 olur. Hangi sayılar arasinda.

Ö15: 7 ile 8

A : Büyük olan sayıyı birim kesrin paydası olacak şekilde kalan $2 / 15$ kesrinden çıkarıyoruz. 2/15-1/8=1/120 zaten kalan birim kesirse işlem bitmiştir. Neleri çıkarmıştım. İlk kesirden $1 / 3$ ve 1/8'i çıkarmıştım. En son 1/120 kalmıştı. O halde 7/15=1/3+1/8+1/120 olmalidır.

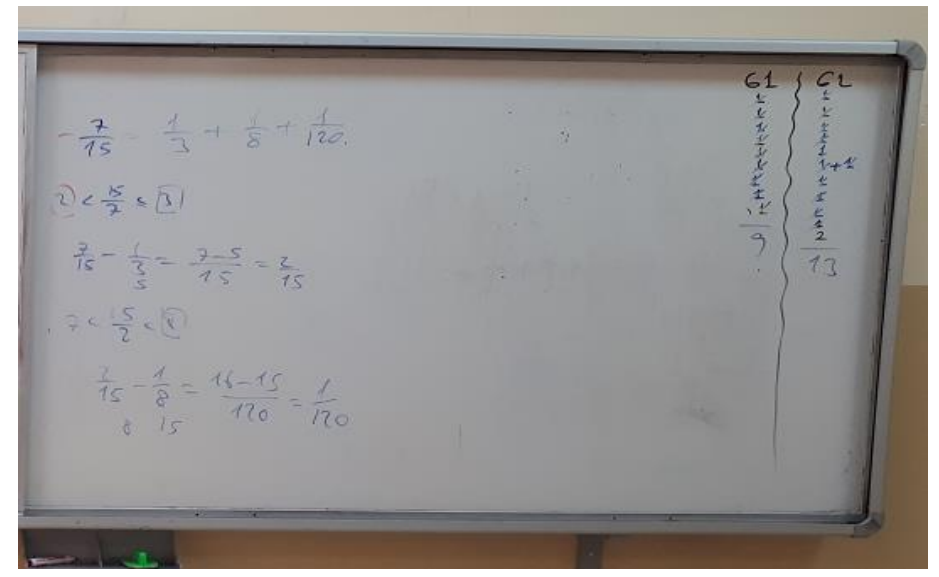

Şekil 3. Kurumsallaştırma Aşamasından Bir Kesit (7/15 Kesri Örneği)

Öğretmen bu aşamada local metotlar olarak ifade edilebilecek $2 /(2 n-1)=1 / n+1 / n(2 n-1)$ ve $2 / n=1 / n+1 / 2 n+1 / 3 n+1 / 6 n$ metotlarının yanında daha genel bir metot olan Fibonacci metodunu açıklamıştır. Ayrıca yarışma bağlamında grup 2'nin hem puan olarak hem de genel kuralı bulması açısından yarışmayı kazandığı da belirtilmiştir. Kurumsallaştırma aşaması 8 dakika sürmüştür.

\subsection{Etkinlik Üzerine Bir Yansıtma}

Bir problemin DDT çerçevesinde tasarlanan öğrenci merkezli bir ortamda öğretmen adaylarına çözüm sürecinin incelendiği çalışmada, öğretmen adaylarının öğrenci merkezli ortamın gerekliliklerine uygun hareket ettiği görülmektedir. Öğretmenin sorumluluk aktarma aşamasında problemi ve problemin nasıl çözüleceğini açıkladıktan sonra kurumsallaştırma aşamasına kadar ortama doğrudan müdahale etmediği anlaşılmaktadır. Adidaktik aşamalar olarak belirtilen bu süreçte öğretmenin sadece ortamı organize ettiği belirtilebilir. Diğer taraftan adidaktik aşamalarda öğretmen adaylarının, öğretmenin tasarladığı oyun çerçevesinde, bilgi-öğrenci ve öğrenci-öğrenci etkileşimiyle problem durumuna ilişkin çözüm yolları (lokal ya da genel) keşfettikleri anlaşılmaktadır. Örneğin bir grubun verdiği hipotez diğer grup tarafından anında doğrulanmaya (onay ya da ret) çalışılmıştır. Böylece ortamda bilgi sürekli gelişmiş ve öğretmen adayları ortaya çıkan bilgi parçacıklarının doğruluğuna kendi ön bilgileri doğrultusunda kendileri karar vermiştir. Dahası problem durumuna ilişkin etkinliğin başında öğretmen 
adaylarının ortaya koyduğu herhangi bir çözüm yaklaşımı tespit edilememesine rağmen etkinliğin ortalarında bu çözümler örtük olarak ve etkinliğin sonunda lokal ve genel yollar olarak açıkça ifade edilmiştir. Dolayısıyla öğretmen adaylarının problem durumuna ilişkin etkinlik başı ve sonu arasında bilişsel açıdan farklılık olduğu belirtilebilir. Yani bilişsel durumlarının zaman içerisinde yeni bilgiyi yapılandırmak için bir arayış içerisine girdiği ve denge halinin bozulduğu anlaşılmaktadır. İlerleyen süreçte ise genel çözümler ortaya koyularak tekrar dengenin sağlandığı belirtilebilir.

Diğer bir önemli boyut etkinlik süresince öğretmenin adaylarının etkinliğin başında didaktik sözleşme (Brousseau, 1997) olarak ifade edilebilecek öğretmenin açıklamalarına uygun hareket etmeleri ve bu sözleşmeye etkinlik boyunca sadık kalmalarıdır. Bu durumun tersine öğretmen adayları etkinlikten sıkılabilir ve etkinlikte sunulan problem durumunun çözüm yolunun ne olduğunu öğretmenden isteyebilirlerdi. Ancak bu tür didaktik sözleşmeyi bozucu bir davranış etkinlik sürecinde ortaya çıkmamıştır. Bu durum öğretmen adaylarının öğrenci merkezli öğrenme ortamlarını teorik olarak bilmelerinin etkisiyle uygulamaya yansıtabilmeleriyle açıklanabilir. Bu süreçte DDT’ye göre tasarlanan ortamın destekleyici bir rol taşıdığı belirtilebilir. Buradan öğretmen adaylarının öğrenci merkezli bir ortamda bilginin nasıl sunulması gerektiği, ortamın tasarımı ve bilginin yapılandırılmasında öğretmenöğrenci rollerine ilişkin eylemlerin farkında olduklarını göstermektedir. Son olarak etkinlik sonunda öğretmen adaylarının etkinliği nasıl buldukları sorulmuştur.

\section{A: Etkinliği beğendiniz mi? (öğretmen adayları evet diye bağırdı) Etkinlik nasıldı?}

Ö5: İyiydi hocam. Güzeldi. Ardında bir defa teorem çıkıyor.

Ö7: İyiydi hocam.

$\mathrm{Bu}$ açıklamalardan öğretmen adaylarının etkinlikten hoşnut kaldığı, problemin çözümünde matematiksel nesneleri özgürce kullandıkları (hipotez ileri sürme, doğrulama, hedef bilgiye ulaşma gibi) ve yapılandırmacı yaklaşıma uygun bir atmosfer oluşturulduğu belirtilebilir. Nitekim Ö5 kodlu ögretmen adayı problem durumuyla başlanan etkinliğin sonunda bir teoremle sonuçlandığını açıklayarak bilişsel durumunu ortaya koymuş ve sınıf tartışmaları sonunda ulaşı1ması hedeflenen bilgiyi yapılandırabildiğini belli ölçüde göstermiştir. Bu yansıtmadan öğretmen adaylarının öğrenci merkezli ortamın birçok bileşeni ile ilgili farkındalık geliştirdikleri ifade edilebilir.

\section{Tartışma ve Sonuç}

Öğretmen adaylarına matematik tarihinden seçilen bir problem durumuyla ilgili öğrenci merkezli bir ortamda çözüm arandığ bu çalışmada, sunulan her göreve öğretmen adaylarının en az bir çözüm ürettiği tespit edilmiştir. Bu çözümlerin ortaya çıkmasında DDT çerçevesinde problemin tasarımı öğelerine odaklanılmasının etkili olduğu belirtilebilir. Teori kapsamındaki problemler rastgele problemler olmayıp, öğrenenlerin çözüm sürecine geçebilmeleri için başlangıç stratejileri içerme, öğrenenlerin hemen çözemeyeceği ama ortamdaki argümanları kullandıklarında çözebilecekleri ve birden çok çözüm yollarının olması gerektiği gibi bileşenlere sahip olması gerekmektedir (Arslan, Baran ve Okumuş, 2011; Bessot, 1994; Gök ve Erdoğan, 2017). Öğrenci merkezli etkinlik tasarımında geleceğin öğretmenlerinin bu tür problemlerin farkında olma ve bunları kurabilmelerinin eğitimde teori ve pratik arasındaki farkı azaltacağı belirtilebilir. Nitekim Penuel, Roschelle ve Shechtman (2007), öğretmenlerin öğrenme durumlarıyla ilgili tasarım sürecine katılmalarının yenilikçi yaklaşımların okullarda kullanılmasında anahtar rol oynadığını belirtmiştir. Öğretmen adaylarına DDT çerçevesinde uygulanan etkinliğin öğrenci merkezli ortamların temel bileşenleri hakkında onlara farkındalık sağladığı ifade edilebilir. Öğretim durumlarında öğrenci merkezli ortamların kullanılmasının istendiği günümüz matematik öğretim programlarında (MEB, 2018a) öğrenci merkezli ortamların kullanımına ilişkin teori ve pratik arasındaki boşluğun giderilmesinin öğretmen adaylarının mesleki gelişimleri açısından da hayati bir öneme sahip olduğu yadsınamaz. 
$\mathrm{Bu}$ çalışmada öğretmen adaylarına verilen görevlerin çoğunda birden fazla çözüm ürettikleri belirlenmiştir. Literatürde öğrencilerin DDT çerçevesinde tasarlanan problem durumuna birden fazla çözüm bulmakta istekli olmadıkları belirtilmektedir (Erümit, Arslan ve Erümit, 2012; Dikkartin Övez, \& Akar, 2018). Bu çalışma problem durumuna ilişkin birden fazla çözüm yolu geliştirilmesi açısından diğer çalışmalardan ayrılmaktadır. Bu çözümler incelendiğinde özellikle eylem aşamasında örtük modeller (örneğin $2 / n=1 / n+1 / 2 n+1 / 3 n+1 / 6 n$ gibi) ortaya çıkmıştır. Bunlar lokal yollar olarak nitelendirilmektedir. Etkinlikte görevlerin kolaydan zora olacak şekilde verilmesi öncelikle lokal yolların bulunmasını desteklemiştir. Daha zor görevlerde lokal yollardan çözüme ulaşılmasının güçleşmesi nedeniyle Ö4 kodlu öğretmen adayının daha sistematik bir şekilde görevleri analiz ettiği ve bu sürecin hemen sonrasında genel bir metot geliştirdiği anlaşılmaktadır. Bu çalışmadaki sonuçlarla benzer şekilde, öğretmenlerin eylemlerinin araştırıldığı bir araştırmada, DDT çerçevesinde sunulan duruma ilişkin öğrencilerin farklı çözüm yaklaşımları üretebildiği ve öğretim sürecinde öğretmenlerin rollerinin bazı çözüm tekniklerinin ortaya çıkmasını etkilediği belirtilmektedir (Sensevy, vd., 2005).

$\mathrm{Bu}$ etkinliğin uygulama sürecinde adidaktik aşamalar (eylem, ifade etme ve doğrulama) iç içe gerçekleşmiştir. DDT çerçevesinde bir problem durumuna çözüm aranması sürecinde adidaktik aşamaların iç içe geçebileceği belirtilmektedir (Dikkartin Övez, \& Akar, 2018; Arslan, Baran ve Okumuş, 2011; Warfield, 2014). Bu süreçlerde özellikle öğrenci-öğrenci (gruplar arası) arasında yoğun bir etkileşim olduğu anlaşılmaktadır. Bu bağlamda bir grubun sunduğu çözümü diğer grup doğrulama (onaylama ya da çürütme) pozisyonu almıştır. Bu sayede öğrenci merkezli ortama ilişkin dinamik yapı korunmuş ve bilgide sürekli ilerleme sağlanmıştır.

Arslan, Taşkın ve Kirman-Bilgin (2015), adidaktik ortamlarda bireysel çalışanların grup çalışması ile karşılaştırıldığında daha başarılı olduklarını belirtmiştir. Bununla benzer olarak etkinlikte grup içi etkileşim sürecinde bilgi paylaşımı, yayılması ve yapılandırılmasına yönelik bireylerin argümanlarından pozitif sonuçlar elde edilmiştir. Örneğin Tablo 2'de Ö3 kodlu öğrencinin eylem aşamasında örtük olarak ulaştığı lokal bir çözüm yolunu ifade etme aşamasında Ö11 kodlu öğretmen adayı açıkça ifade etmiştir. Bu durum bilginin grup içinde yayılmasında bireysel kazanımların sınıfın kazanımına dönüşmesinde DDT'nin etkili bir şekilde kullanılabileceğini göstermektedir.

Öğretmen adayları etkinlik süresince öğrenci merkezli ortamın şartlarını bozacak bir girişimde bulunmadığı tespit edilmiştir. Öğrenci merkezli ortamları daha önce deneyimlemeyen (Bkz. yöntem) öğretmen adaylarının öğrenci merkezli ortamları teoride bilmeleri ve etkinliğin başarılı bir şekilde gerçekleştirilmesinin sonucunda uygulamada herhangi bir adaptasyon sorunu yaşanmamıştır. Bu durum öğretmen adaylarının öğrenci merkezli ortamlarla ilgili bileşenlerin (örneğin bilgiyi bireyin kendisi ortam ile etkileşim sürecinde bilişsel durumunun elverdiği ölçüde yapılandırması) farkında olduklarını işaret etmektedir.

Bu çalışmada öğrenci merkezli bir ortamda öğretmen adaylarının bir problem durumunu çözme sürecinde öğrenci merkezli ortam tasarımının öğelerini içselleştirdiği söylenmemektedir. Bunun yerine öğrenci merkezli ortamın bileşenlerine ilişkin öğretmen adaylarında bir farkındalık oluşturulduğu belirtilmektedir. Diğer taraftan öğretmen adaylarının öğrenci merkezli ortamlara ilişkin deneyimlerin lisans yıllarında sayısının arttırılmasının teorik bilgi ile pratikte bunun kullanımı arasındaki boşluğu giderme potansiyeli taşıdığı düşünülmektedir. Çalışmada elde edilen sonuçlar doğrultusunda şu öneriler verilebilir:

1. Öğretmen adaylarının mesleki gelişimleri açısından, öğrenci merkezli ortamlara ilişkin teori ve pratiğin bütünleştirilebildiği lisans düzeyinde derslerin arttırılması önerilebilir.

2. Araştırmacılara, öğretmen adaylarına öğrenci merkezli ortamlarda uzun süreli deneyimler yaşatılarak, onların bu tür deneyimleri staj dönemi ve sonrasında kendi sinıflarında kullanma durumları, bu süreçte karşılaştıkları engelleri ve bu engellerin nasıl üstesinden gelinebileceğine ilişkin çözüm önerilerini ortaya koyacakları bütüncül çalışmalar yapmaları önerilebilir. 


\section{KAYNAKÇA}

Arslan, S., Baran, D. \& Okumuş, S. (2011). Brousseau'nun matematiksel öğrenme ortamları kuramı ve adidaktik ortamın bir uygulaması. Necatibey Eğitim Fakültesi Elektronik Fen ve Matematik Ë̆itimi Dergisi (EFMED), 5(1), 204-224.

Arslan, S., Taşkın, D. ve Kirman-Bilgin, A. (2015). Adidaktik öğrenme ortamlarında bireysel ve grup çalışması uygulamalarının öğrenci başarısına etkisi. Türk Bilgisayar ve Matematik Ĕgitimi Dergisi, 6(1), 47-67.

Artigue, M. (1994). Didactical engineering as a framework for the conception of teaching products. R. Biehler, R. W. Scholz, R. Strasser ve B. Winkelmann (Ed.), Didactics of mathematics as a scientific discipline içinde (s. 27-39). New York: Kluwer.

Baki, A. (2014). Matematik tarihi ve felsefesi. Ankara: Pegem A Akademi.

Bessot, A. (1994). Panorama del quadro teorico della didactica matematica. L'Educazione Matematica, 15(4).

Brousseau, G. (1997). Theory of didactical situations in mathematics: Didactique des mathématiques, 1970- 1990. Dordrecht: Kluwer.

Burton, D. M. (2011). The history of mathematics: An introduction (seventh edition). New York: McGraw-Hill.

Çelik, D., Güler, M., Bülbül, B. Ö., \& Özmen, Z. M. (2015). Reflections from a learning setting designed to investigate mathematical thinking. International Journal of Educational Studies in Mathematics, 2(1), 11-23.

Çepni, S. (2009). Araştırma ve proje çalışmalarına giriş. Trabzon: Celepler Matbaacılık.

De Holton, D., Ahmed, A., Williams, H., \& Hill, C. (2001). On the importance of mathematical play. International Journal of Mathematical Education in Science and Technology, 32(3), 401415.

Dikkartin Övez, F. T. \& Akar, N. (2018). The investigation of process of teaching function concept in an Adidactic learning environment. Pegem Eğitim ve Ögretim Dergisi, 8(3), 469-502, http://dx.doi.org/10.14527/pegegog.2018.019

Erdoğan, A., \& Özdemir Erdoğan, E. (2013). Didaktik durumlar teorisi 1şığında ilköğretim öğrencilerine matematiksel süreçlerin yaşatılması. Ahi Evran Üniversitesi Kırşehir Eğitim Fakültesi Dergisi, 14(1), 17-34.

Erümit, A. K., Arslan, S., \& Erümit, S. F. (2012). Bir matematik probleminin adidaktik ortamdaki çözüm süreci. Ë̆itim ve Öğretim Araştırmalart Dergisi, 1(4), 75-81.

Fried, M. N. (2001). Can mathematics education and history of mathematics coexist? Science \& Education, 10, 391-408.

Gök, M., \& Erdoğan, A. (2017). Sınıf ortamında rutin olmayan matematik problemi çözme: Didaktik durumlar teorisine dayalı bir uygulama örneği. Yüzüncü Yıl Üniversitesi Eğitim Fakültesi Dergisi, 14(1), 140-181.

Hargreaves, A. (1996). Transforming knowledge: Blurring the boundaries between research, policy, and practice. Educational Evaluation and Policy Analysis, 18(2), 105-122. 
İnan, C. ve Özgen, K. (2008). Matematik öğretmen adaylarının öğretmenlik uygulaması sürecinde öğrencilere düşünme becerilerini kazandırmadaki yeterliliklerine yönelik görüşlerinin değerlendirilmesi. Elektronik Sosyal Bilimler Dergisi. 7(25), 39-54.

Karakuş, F. (2009). Matematik Tarihinin Matematik Öğretiminde Kullanılması: Karekök Hesaplamada Babil Metodu. Necatibey Eğitim Fakültesi Elektronik Fen ve Matematik Eğitimi Dergisi (EFMED), 3(1), 195-206.

Laborde, C. (2007). Towards theoretical foundations of mathematics education. ZDM Mathematics Education, 39, 137-144.

Malik, M. A. (1980). Historical and pedagogical aspects of the definition of function. International Journal of Mathematical Educational in Science and Technology, 11(4), 489-492.

Merriam, S. B. (2013). Nitel vaka çalışması (Çev: E. Karadağ). S. Turan (Ed.), Nitel araştırma desen ve uygulama için bir rehber içinde (3rd ed.). Ankara: Nobel.

Milli Eğitim Bakanlığı [MEB]. (2018a). Matematik dersi ögretim programı (ìlkokul ve Ortaokul 1, 2, 3, 4, 5, 6, 7 ve 8. Sinfflar). Ankara: Milli Eğitim Bakanlığı.

Milli Eğitim Bakanlığı [MEB]. (2018b). 2023 eğitim vizyonu. Ankara: Milli Eğitim Bakanlığı. Retrieved December 27, 2018, from http://2023vizyonu.meb.gov.tr/doc/2023_EGITIM_VIZYONU.pdf

OECD (2017), PISA 2015 Results (Volume V): Collaborative Problem Solving, PISA, OECD Publishing, Paris, https://doi.org/10.1787/9789264285521-en.

Özgür, Z., Bukova-Güzel, E., Kula, S., \& Uğurel, I. (2009). Matematik öğretmen adaylarının gözünden liselerdeki mesleki ön uygulama deneyimlerine yönelik süreçlerin resmi. İnönü Üniversitesi Eğitim Fakültesi Dergisi, 10(3), 227-252.

Penuel, W.R., Roschelle, J. and Shechtman, N. (2007) 'Designing formative assessment software with teachers: an analysis of the co-design process', Research and Practice in Technology Enhanced Learning, Vol. 2, No. 2, pp.51-74.

Sensevy, G., Schubauer-Leoni, M. L., Mercier, A., Ligozat, F., \& Perrot, G. (2005). An attempt to model the teacher's action in the mathematics class. In Beyond the apparent banality of the mathematics classroom (pp. 153-181). Springer, Boston, MA.

Tzanakis, C., \& Arcavi, A. (2000). Integrating history of mathematics in the classroom: An analytic survey. In J. Fauvel, \& J. van Maanen (Eds.), History in mathematics education (pp. 201-240, Chapter 7). The ICMI Study. Dordrecht: Kluwer Academic Publishers.

Yıldııım, A. ve Şimşek, H. (2016). Sosyal bilimlerde nitel araştırma yöntemleri (10. Baskı). Ankara: Seçkin Yayıncılık.

Yüksek Öğretim Kurulu (2007). Öğretmen yetiştirme ve eğitim fakülteleri (1982-2007). Ankara: Yükseköğretim Kurulu Yayını 2007-5. https://www.yok.gov.tr/Documents/Kurumsal/egitim_ogretim_dairesi/Ogretmen-

Yetistirme/2.pdf> 19.08.2019 tarihinde alınmıştır.

Yüksek Öğretim Kurulu (2018). Yeni öğretmen yetiştirme lisans programlarl. https://www.yok.gov.tr/Documents/Kurumsal/egitim_ogretim_dairesi/Yeni-OgretmenYetistirme-Lisans-Programlari/Ilkogretim_Matematik_Lisans_Programi.pdf > 22.08.2019 tarihinde alınmıştır.

Warfield, V., M. (2014). Invitationto didactique. New York: Springer. 